\title{
Good-Life Concepts of Moral Value in Robin Hood Movie
}

\author{
Faidah Yusuf \\ faidah.yusuf@uin-alauddin.ac.id \\ English and Literature Department. Universitas Islam Negeri Alauddin Makassar. Indonesia , \\ Ince Fachrunnisa \\ ichafachrunnisa74@gmail.com \\ English and Literature Department. Universitas Islam Negeri Alauddin Makassar. Indonesia ,
}

\begin{abstract}
The study aims to know good-life concepts of moral value in Robin Hood movie. This research used qualitative approach. The researcher found that five moral principles are tolerance, belief, kind-hearted, integrity, and responsibility. In this movie, good-live concepts of moral value are tolerance for human relationships with Heaven, belief is entrusting everything to God's power, kind-hearted is honesty in this movie that the hero succeeded in winning people's hearts by his supporting honesty, integrity is like finding a valuable gem, and responsibility portrayed feels responsible for defense, reminding people of responsibility to protect their position in everywhere.
\end{abstract}

Keywords: Belief; Honesty; Kind Hearted; Moral Value

\section{INTRODUCTION}

Moral in literary work typically represents the author's belief in "goodness." Whose conviction is transmitted to readers or listeners, Further, (Nurgiyantoro, 2018) stated the moral as the whole story's message. It can be used as role model "guidelines."

Educational value is concerned with cultivating desirable mindsets in communicating what is worthwhile to those who care for these important items themselves. (Peters \& Cooper, 1986) said that educational value is the principle of meaning and law that contributes to a person's proper definition, or an awareness that other people count or other people's graphs count or comprehend emotions. Educational principles related to establishing other facets of this education: personality, morality, ethics, etc.

Moral dilemmas in psychology play a crucial role in exposing the nuances behind our moral decisions. To grasp the foundations of moral thought (Magid \& Schulz, 2017). Tolerance is important to share our feelings, but it is also important. And have the confidence to talk to what we believe (Avery et al., 1997). Moral value on an equal footing between sensual and esthetic meaning. For example, some non-moral values that fishing undergoes transmutations in other ways. But it is particularly with moral values: some accurses include transmuting means into ends, training, and maybe some do not necessitate training. Training in moral importance was ignored or shown to be feasible. Their principles are so organized that these people can maximize their happiness by cheating on our good behavior. Moral values are more unitary between individuals and people than many sensual and esthetic values by virtue of their social character. (Goldman \& Kim, 1978)

Moral value is the ideals of good-life concepts. The controversy about the principles that make up good life is persistent. Moral value is the rational concept that is real or false and good or bad an idea or action or human nature. Social morality determines how our climate, our immediate society and the global community are discussed. Value found in the film, too. Values comprise in the film the values that the teacher will use to turn the side of education. Teachers teach not only English, but teachers often convert the importance of making students feel comfortable. Films can be an outstanding tool for learning English and for getting constructive reviews. By watching the film, 
people are able to absorb the positive meaning. The ideals of the film with inspirational subjects are the best that the writer can see and explore. One of the inspirational films is "Robin Hood," a legendary British villain. Robin Hood was a skilled archer and swordsman according to legend. He said to have been a noble character in the Crusades, Robin Hood. Then in England, Robin Hood returned to his home country. The sheriff of Nottingham took the land up in England. It is identified as being born into a class of noble domestic helpers from the folklore of Robin Hood. This time is slightly different from the costume worn in the 2018 Robin Hood movie, in particular.

Literature can be characterized simply as a creative practice, as an artistic work. The purpose is to entertain the readers in literature. The researcher wants to examine morality of tolerance, belief and child-heartedness in Robin Hood 's film The researcher hoped this analysis will help establish moral values derived from Ben Chandler 's film Robin Hood

\section{Literature}

It is the representation of life in literature. Some experts have different opinions regarding their meaning of time- and social-related literature. The nuances of literature as life are responsible for these diverse views. (Pratt et al., 2003) It notes that literature is yet another way that our imagination can perceive the word around us. All published materials include literature in the broadest context. History books, philosophy, novels, poetry, science papers, dictionaries, instructional guides, travel brochures, magazines, school books are part of this general category..

The Concept of Value

It notes that literature can interpret the word around us in a different way. In the broadest sense, all publications include literature. The general category includes books on history, philosophy, fiction, poetry, science, dictionary, teaching guides, tourist books, magazines and school books.. (Raz, 2006), The word "value" may mean that decisions or decisions are useful as individuals enjoy them or, right or wrong, uplifting and fundamental, reasonable or unjust and more personal preferences. Worth is something pleasing, something caring, and something positive in short meaning. Value has a strong sense (Magid \&
Schulz, 2017).

Moral Value

Moral worth issues with respect to the positive or bad behavior and personalities of human beings. Morality is about what is good or right in the relationship between people. Morality interpretation must be unique to good (or bad) and good (or wrong) meanings, so these words can be used in many ways. (Sternberg, 2012). Therefore, moral meaning will direct people to determine correctly and wrongly. And it can distinguish between right and wrong actions. There are some universal principles which have been argued (Harris, 2010) such as:

\section{Tolerance}

Tolerance is able to consider various attitudes and values, while you do not endorse or embrace them. (Harris, 2010) Arguing that the notion of the glib that everyone is free to value anything gives rise to very realistic concerns. The most significant thing is that it helps highly educated, secular and generally well-meaning people to pause extensively and sometimes indefinitely before criticizing their activities. Everyone must also understand other values and conduct.

\section{Belief}

Belief is a condition or habit that has confidence, trust, trust and faith in someone. Belief is something that the proponents of all types of opinions believe, claims or arguments, beliefs about the truth or the reality of a specific being and phenomenon, particularly when it is focused on an analysis as to why the argument is accepted as true or incorrect.. (Pölzler \& Wright, 2020).

Kind-hearted

Kind is the equivalent of what has offered or received. Kind is applying more often to the disposition to sympathy and helpfulness. Kindly is stressing more the expression of the sympathetic, helpful nature, mood or impulse (a kind person with a kindly interest in the problem of other). Kindhearted is having sympathetic nature: humane, compassionate. Kindheartedness is the quality or state of being kindhearted (Heiphetz et al., 2013)

\section{Honesty}

Honesty is an estimate of its essence, its honesty and its straightforwardness. Honesty is 
subtlety or duplicate honesty and sincerity (Grosch \& Rau, 2017).

Responsibility

Being responsible is to have control and authority over something or someone and the duty of taking care of it or them (Giddens, 1999). Social responsibility is a philosophy of ethics that implies that an individual, be it an organization or a person, is obligated to act in the interest of society in general. Social responsibility is the obligation that each person must fulfill so that the economy remains in harmony with the ecosystems. The products of a process of recognizing the importance of God and mankind in creation are moral principles. These principles will properly direct human understanding and imagination (Killen \& Verkuyten, 2017). Morality is split into two parts; values and morality are personal and social. Personal morality determines how we respond directly to life from or beyond our personal integrity. Social morality determines how our climate, our immediate society, and the global community are treated. Our sense of what is right and what is wrong direct us all individually. We still have to be socially driven. Morality is a message or lesson from a story or incident in the literature.

\section{METHODS}

This section discusses the nature and implementation of the research design used in this report. All researchers plan and strategy to respond to research issues of study can be described as research design. (Ary et al., 2010) The research design was claimed to be the strategy for researchers to gain an understanding in their natural environment of certain groups or phenomena. The thesis used a library research or content analysis for research design. (Ary et al., 2010), content analysis belongs to qualitative approach is one in which the inquirer often makes knowledge claims based primarily on constructivist perspective (Creswell, 2014). In this research, the researcher took the data from the movie "Robin Hood Movie by Ben Chandler to analyze the moral value by using (Harris, 2010) theory. This movie was released in 2018, has duration 116 minutes

\section{RESULTS AND DISCUSSION}

Moral value is to be specific about definitions of good or bad, right or wrong, since these terms can be used in several different ways. Moral values in literary works then, mean the principle of right or wrong behaviors which are worthwhile and important in a literary work to be conveyed to the readers to improve their moral standard. Kinds of moral values portrayed in this movie based on (Harris, 2010) are:

\section{Tolerance}

Tolerance is willingness to accept behavior and beliefs which are different from one and other, although you might not agree with or approve of them.

Gisbourne: I am God's true soldier, Loxely. I deserve a....

Marian : He had it coming.

Nottingham local citizens come together to attempt to attack a government that gives all the people's land. At the time of this assault, there was a remarkable upheaval and Robin and his troops attempted to capture the house, but Gisbourne blocked him and charged him immediately. A struggle broke out between both and Robin managed to bring Gisbourne down. Robin could however not afford to destroy Gisbourn because he felt like he owed his life to Gisbourne. So Robin released and left Gisbourne even though at the time he had a chance to end Gisbourne who was a nottingham elite army.

Yahya : I was born into this war but I"ve never met a man who had his killing coming as much as you do. You're gonna wanna believe in god. You're gonna want to see his face and think that something can save you. But, you'll see my face and that's the last thing you'll see. InsyaAllah!

Shariff : (Leave Yahya in the Jail).

For the first time, Robin again stealed coins obtained from people by the government and was helped by Yahya this time to make it easier to flee, Robin managed to get several coins again to the public, but the operation was carried out by government forces before he went ahead. Yahya picked up Robin in a horse carriage immediately and attempted to flee, but they were drived away 
and surrounded by soldiers before Yahya eventually sacrificed himself to let Robin flee. He was targeted by the sheriff before Yahya was imprisoned and stripped of his faith, the faith of Islam by the Sheriff. But Yahya remained patient with the Sheriff, and she explained that one day, God revealed his grandeur and wonders to the Sheriff He continued to incite Yahya 's rage.

Belief

Belief is a state or habit on mind in which trust, confidence, reliance, is place in some person or thing. Belief also talks about opinion or something that a person holds to be true.

Yahya : You"re only powerless, if you believe you're powerless. Follow me, England.

Robin : Ok!

When Robin returned to Nottingham he was very happy to meet Marian idol of the heart again, but he learned that Marian had a husband, and he heard the news that Robin died in the battle a few years earlier. Robin was so angry and upset that Marian was watching Marian walking away with her husband, when Yahya met him at that time and offered him a job together. However, the Arabs' soldier who tried to end him in the field of war, Robin did not believe in Yahya. Without him understanding that Yahya entered their boat to pursue Robin who tried to save his first son to be executed by Gisbourne, this was why he chose Robin in order to work together against the Nottingham government. The administration and the Yahya Child's death will avenge..

Yahya : I don"t cross on ocean to watch you crawl into a bottle. Maybe she will love you again, InshAllah, when she finds out the truth of what we're doing. But not before then.

Robin : Well, the let's get on with it.

Finally, Robin believed and supported the offer of Yahya to work together against the brutal government of Nottingham. Before Robin's two went home and spoke, Robin proceeded to practice arrow training after discussion so that he could do more with the arrow and later start the event while training Yahya. Suddenly Merian came and yelled out of the house and called for his name, as he wanted to see if his lover Robin, who had been declared dead five years earlier on the battlefield, was really the one he had seen. Robin noticed Marian and was so happy she was going to go to
Marian and say hello, but Yahya banned her, because she was just coming to Nottingham to prepare. Yahya is terrified, Marian will discover her plans and become a barrier. That was when John informed Robin that Marian, InshaAllah, was going to return to God later. Until Robin believed and met Marian, he didn't.

\section{Kind-Hearted}

Kind is the equivalent of what has offered or received. Kind is applying more often to the disposition to sympathy and helpfulness. Kindly is stressing more the expression of the sympathetic, helpful nature, mood or impulse (a kind person with a kindly interest in the problem of other).

Robin : I'm sorry I couldn't save him.

Yahya : But you tried to. In all my years of war, I've never seen anything like it. That's why I chose you.

Robin : Chose me? What for?

Yahya : This war, all wars, and everything happening here, it"s as old as time.

All cruisaders returned to England after the war in the Arab lands had ended. On his path back to Nottedham Robin returned home because he was wounded by trying to support Yahya, when his son was being murdered by his friend Gisbourne and was returning home. Robin was one of the noble people in Nottingham. Yahya then considered Robin different from other crucifixes, and Robin still had his heart, though Robin did not stop Gisbourne from helping him, trying to save his son Saleem. But, in Robin 'S resistance to Gosbourne 's actions, Yahya also tried to help Robin remove governmental measures which made his people miserable after he reached Nottingham. His resistance made Robin reward Robin for Robin's mess, too. Robin initially declined, but Yahya would not abandon to persuade Robin to help Robin who was wounded when battling his troops for Yahya. This is when they met again. Robin promised to cooperate. They eventually agreed and returned to the old residence of Robin for the creation of a resistance strategy.

Robin : Wait! The commoners love this worm. And I think he wants to be their martyr. So let's give him a fate worse that death. Revoke his church. Defrock him! And throw him to the streets. That should cut him a little deeper that any 
blade could.

Tuck : Don't! You can't! Your Grace, please!

In Nottingham, the sheriff and church priest are busy talking about proposals for the redistribution of land they received from the ordinary people. And then Tuck was unexpectedly caught stealing the keys to the store and valuable state papers, when the Sheriff immediately ordered his soldiers to kill Tuck who had deceived him, and Robin came and tried to foil the plan to kill Tuck by presuming to snapshot him and punish him more painfully than to kill. By lying like this in front of the Sheriff and Priestess, Robin attempted to save Tuck 's life before Sheriff believed Robin and canceled Tuck, but he fired his job at his placement.

\section{Honesty}

Honesty is estimable character, fairness and straight forwardness of conduct or adherence to be fact. Honesty also is a facet of moral character that connotes positive and virtuous attributes such as integrity, truthfulness, including straight forwardness of conduct, along with the absence of lying, cheating, theft, etc.

Robin : Ah... So you're an admirer.

Marian : He has his qualities.

Will : Marian, there you are.

One of the devious plans of the Nottingham government is to hold a massive party specifically for rich people because they provide various Sorts of games to cheat the affluent by gambling. Robin was also invited because he was one of the nobles who always gave plenty of tax money, was very nice and generous. Marian was also present because he was the representative of the people of the subordinates of Notthingham. When they met, people spoke about a man who wore a hood and stole the people's tax money, then Marian whispered to Robin and admitted he was fascinated by the courageous person. While Hood was robbing, the results are still shared with the tiny people who surprise and convey it to Robin. The mystery figure The man he considered a hero, unknowingly knew, was concealed by Robin. Then Will comes unexpectedly and invites Marian to make him jealous.

Responsibility
Being responsible is to have control and authority over something or someone and the duty of taking care of it or them. Responsibility is the burden someone is obligated to fulfill in order to meet a particular need. Someone's level of meeting his responsibilities shows how trustworthy he is, particularly if he consistently meets his responsibilities.

Yahya : I don't have anything else! He's my son. I'm just trying to save my son.

Gisbourne : Well, if it's any consolation

Saleem : Baba save me! Gisbourne : You can"t.

The Arab army was defeated by the crucifixionists when the war was over, it wasn't over. Gisbourne who was the leader of the crucifixions was very cruel. He massacred young soldiers and one of them was Yahya bin Umar's Saleemss, a leader of the Arab Army, after capturing all the other Arab soldiers. When Saleem was about to be killed, Yahya tried in many ways to save his son. One of these was to substituten the place of his son, but Gisbourne refused to give Yahya the strategies of the next Arab army and asked Yahya to give him information. But Gisbourne was not satisfied and proceeded to cut Saleem 's head off from Yahya, as Yahya said unwillingly, with the intention of saving his brother. Robin then rebelled and fought against Gisbourne for the failure to kill innocent children, but Gisbourne shooted Robin and returned them all to Nottingham.

\section{Discussion}

Discussing of the moral values portrayed in the movie.

\section{Tolerance}

Tolerance means tolerance for the various views, viewpoints and conducts and practices. Tolerant person is typically optimistic, tolerant of other points of view, constructive. Tolerance is an attitude of mutual tolerance, respect and aid in social ties between groups and individuals. Even if we are in an immediate situation, a healthy tolerance is always in place and it can have a positive effect on us and the world if we value others. The comparison of moral values in these two separate literary works was based on the fact that in the study the researcher found the characters' high sense of tolerance in this film, which allows moral values to appear on the 
tolerance aspect seen in the film. Tolerance in this film is not only connected to human relations, but is focused on aspects of human relationship with God in this film tolerance.

\section{Belief}

Belief and confidence is an attitude exhibited by humans when they believe they know enough and when they think they have come to the facts. As faith is a mindset, one's convictions are not always valid or literally convictions aren't assurances of truth. Belief is a willingness of a person to rely on those who believe in him. Trust is also one of the living provisions that we need to safeguard. Since life is full of doubt and lies without faith. Trust will develop if someone tries to save others in a bad situation. Then, it is to demonstrate honesty, honesty and dedication to help to persuade one another to trust. Believe is the wise conduct of someone who should be rewarded, because it is not easy to give the predicate of confidence in others. The dependence on the match between words and actions cannot be achieved by the degree of reinforcement.

When one of the characters is in order to persuade someone, let alone stuff about emotions, the moral meaning of this movie is revealed. The effort to create trust in the scene is extremely strong because one figure called Yahya persuaded Robin to confide in God's greatness his feelings. If all we depend on the Almighty, our trust in the effects of patience is strong. When Yahya persuaded Robin not to meet Marian for the wrong time and left all things to God's control, the moral meaning of believing this scene is demonstrated.

\section{Kind-Hearted}

Kind hearted does not only include giving, forgiving or let go. However, regret is also included in Kind hearted; sometimes someone is very sorry for having failed to help people who really want to be helped due to circumstances that do not support. The reason researcher chose this scene as kind hearted was because Robin felt very sorry for failing to save the son of Yahya who was executed by his friend who was a crusader from Nottingham. Robin still feels compelled to help the children of Yahya for humanitarian reasons. Robin's kindness was reflected in her sincere apologies and felt sorry for Yahya.

The attitude and helpful nature of help are also part of Kind hearted. In social life, we must prioritize kindness so that life can be harmonious and peaceful. Helping others when in distress can also have a positive impact on oneself, giving a sense of peace and sincerity. Although often a person must be forced to lie to help others. That is the reason why the researchers chose this scene which contains moral values in its main life in kind heated. as happened when Robin was forced to lie to Sherriff so as not to kill Tuck.

Honesty

In this film, honesty is depicted when Marian admits that Mariam greatly admires Robin for the hero they call Hood, Marian expressed her honesty before the audience, and the people around her responded well. The honesty displayed in this film has strong links to social life, honesty is very important because honesty can run smoothly and peacefully, because lies have an adverse effect on yourself, others and the world. This is the reason why the scientist chose this scene and wanted to include it in a truthful feature in the field of moral values. Honesty is a means of revealing one's real identity. Who, in words and deeds, is always honest, while bitter and dangerous, can be sure of a strong moral integrity. All around us can be confident and safe, with high honesty. This is why the scientists chose this scene because Robin Hood is wary of telling people his true identity that Robin Hood is like Robin to help them battle an oppressive and arbitrary government. It does have threats and can jeopardize the life of Robin.

\section{Responsibility}

The reason to choose this scene as an element of responsibility is because the character in this character displays a great responsibility to save his brother. Every effort has been made to save his child as valuable in his life. In this scene, a father's duty to his child is exemplary, his high sense of security, ownership, and father love is clearly demonstrated. This was demonstrated when Yahya tried to save his son by disclosing his troops' war plan to cruel crusaders. In this study, we can see certain universal principles drawn across scenes very closely linked to our social life. Some moral principles portrayed in this film like tolerance, belief, kind-heartedness, integrity and duty are close to our lives. We should apply the moral principles of the Robin Hood 2018 film in 
everyday life. In fact, in any literary work that contains moral values that we can take and learn, everything depends on the reader's or audience 's view of the literary work.

\section{CONCLUSION}

Good-life concepts of moral value in Robin Hood are 1). Tolerance represented when Robin and Gisbourne fought and they still recall their memory when they were in Arab war, and Yahya demonstrated to Sheriff when Yahya was locked up in prison, 2). Belief in this film represented when Yahya persuaded Robin to work together before Robin believed what he said, and when Yahya made Robin believe that Marian would love him again because of God. 3), The third is KindHearted, even in the scene Robin apologizes to Yahya for not being able to save his brother, and the second is when Robin saved Tuck when the Sheriff was about to kill him, 4). Honesty in this film when Marian honesty eventually admitted his love for Robin Hood and Robin Hood honestly and exposed his true identity so that people can believe and fight for him, and 5). Responsibility displayed when Yahya feels responsible for the protection of his child, and Marian reminded people of responsibility to protect their position.

\section{REFERENCES}

Ary, D., Jacobs, L., \& Sorensen, C. (2010). Introduction to Research Education. 8th Edition. Wadsworth Cengage Learning.

Avery, P. G., Sullivan, J. L., \& Wood, S. L. (1997). Teaching for tolerance of diverse beliefs. Theory into Practice, 36(1), 32-38. https://doi.org/10.1080/00405849709543742

Balon, R. (2020). Kindhearted Inspector in Pursuit of Motives and Truth. Academic Psychiatry, 1-2. https://doi.org/10.1007/s40596-02001305-x

Creswell, J. W. (2014). Research Design Qualitative, Quantitative, and Mixed Method Approaches. SAGE Publication, Inc. https://doi.org/https://b-

ok.asia/book/3700358/d95149

Giddens, A. (1999). Risk and Responsibility. Modern Law Review, 62. https://heinonline.org/HOL/Page?handle=hein.jour nals $/$ modlr62\&id $=15 \&$ div $=\&$ collection $=$
Goldman, A. I., \& Kim, I. (1978). Values and Morals. https://philpapers.org/rec/GOLVAM

Grosch, K., \& Rau, H. A. (2017). Gender differences in honesty: The role of social value orientation. Journal of Economic Psychology, 62, 258-267. https://doi.org/10.1016/j.joep.2017.07.008

Harris, S. (2010). The Moral Landscape. In The New York Times. http://www.nytimes.com/2010/10/03/books/review /Appiah-

t.html?pagewanted=2\&_r $=1 \& n l=$ books\&emc $=$ book supdateema4

Heiphetz, L., Spelke, E. S., Harris, P. L., \& Banaji, M. R. (2013). The development of reasoning about beliefs: Fact, preference, and ideology. Journal of Experimental Social Psychology, 49(3), 559-565. https://doi.org/10.1016/j.jesp.2012.09.005

Killen, M., \& Verkuyten, M. (2017). The importance of social-cognitive development and the developmental context for group dynamics. Group Processes and Intergroup Relations, 20(5), 707-718. https://doi.org/10.1177/1368430217711771

Magid, R. W., \& Schulz, L. E. (2017). Moral alchemy: How love changes norms. Cognition, 167, 135-150.

https://doi.org/10.1016/j.cognition.2017.03.003

Nurgiyantoro, B. (2018). Teori pengkajian fiksi. https://scholar.google.com/citations?user=18INt5g AAAAJ\&hl=en\&oi=ao\#d=gs_md_cita$\mathrm{d} \& \mathrm{u}=\% 2 \mathrm{~F}$ citations $\% 3 \mathrm{Fview}$ _op\%3Dview_citation \%26hl\%3Den\%26user\%3Dl8INt5gAAAAJ\%26citati on_for_view\%3Dl8INt5gAAAAJ\%3Au5HHmVD_ uO8C\%26tzom\%3D-420

Peters, R. S., \& Cooper, D. E. (1986). Education, Values, and Mind: Essays for R.S. Peters. https://philpapers.org/rec/PETEVA

Pölzler, T., \& Wright, J. C. (2020). Anti-Realist Pluralism: a New Approach to Folk Metaethics. Review of Philosophy and Psychology, 11(1), 5382. https://doi.org/10.1007/s13164-019-00447-8

Pratt, M. W., Hunsberger, B., Pancer, S. M., \& Alisat, S. (2003). A Longitudinal Analysis of Personal Values Socialization: Correlates of a Moral Self- Ideal in Late Adolescence. Social Development, 12(4), 563-585. https://doi.org/10.1111/1467-9507.00249

Raz, J. (2006). Reason and Value Themes from the Moral Philosophy. Clarendon Press, Oxford.

Sternberg, R. J. (2012). Teaching for Ethical 
Reasoning. International Journal of Educational

https://doi.org/10.4471/ijep.2012.03

Psychology

(IJEP),

$1(1)$, 35-50. 